\title{
Effect of Planting Position, Pruning and Size of Slip on the Vegetative Development of Pineapple (Ananas comosus) (L) Merr. cv. Smooth Cayenne ${ }^{1}$
}

\author{
Francisco L. Jordän-Molero ${ }^{2}$
}

\begin{abstract}
Vegetative development of 12-month-old Smooth Cayenne plants was observed as alfected by planting position, slip pruning and slip size. Data taken included plant height, spread, leaf number and " $D$ "-leaf weight, length, width and thickness. Results showed that vegetative development was not affected by planting in a vertical or inclined position. Plant height, number of green leaves, and "D" leaf weight were negatively affected when slip leaves were pruned although reduction in leaf area is supposed to affect fruit yield. There was no difference among the three pruning treatments. Size of slips showed highly significant differences in all variables observed with the exception of leaf width. Vegatative development was proportional to slip size even though climate and soil conditions were very lavorable to growth and development. Growth was vigorous and succulent. Correlation coefficients between all variables studied were highy significant. Plant weight, slip weight, stem weight and stem diameter showed consistent correlation values. Mean comparisons present data grouping on two levels. Slip weight under 200 grams did not show good development.
\end{abstract}

\section{INTRODUCTION}

Region, planting date and variety are some of the factors that affect behavior of slips, suckers or crowns of various sizes and weights used in the propagation of pineapple plants. It depends on how long they can grow before flower differentiation to determine advantages or disadvantages of any planting material of a given size or weight. Results reported in several countries present different findings according to climate, growing period, flower induction, soil, moisture, and other regional factors, as well as season and variety.

Research in Hawaii from the Pineapple Research Institute (unpublished data) showed that in the first season crop there was a significant correlation between size of slip and fruit. Correlation was also significant for the second (ratoon) crop with tonnage per hectare, although not necessarily with average weight of fruit. There was a high correlation between fruits per plant and slip size. Sucker production showed no difference but small slips produced inferior suckers unable to produce a second fruit. Slips were classified in four groups ranging from 85 to 425 grams.

\footnotetext{
${ }^{2}$ Manuscript submitted to Editorial Board January 31, 1985.

${ }^{2}$ Horticulturist, Department of Horticulture, College of Agricultural Sciences, Mayagüez Campus, University of Puerto Rico, Mayagüez, P.R. 00708
} 
Gadelha et al. (11), working with Perola in Brazil, found that heavier slips (180-200 g) fruited earlier. After 6 months $45.8 \%$ of them produced a fruit but none in the $100-\mathrm{g}$ weight flowered. Above the $130 \mathrm{~g}$ many of the fruits produced were of no commercial value. They concluded that slip weight is a very important factor affecting flower-bud formation.

In another experiment Gadelha (10) using four sizes of Perola (55-200 $\mathrm{g}$ and $20-55 \mathrm{~cm}$.) concluded that height and leaf number were greater in plants originating from larger and heavier slips. The same results applied to the fruit. Fruiting period required 534 days for heavier slips and 557 for smaller ones.

According to Gaillard (14) increase in fruit weight is a function of slip weight or any other planting material used.

Fortes (9), working with Yellow Flesh Pernambuco planted in April and harvested 19 months later, concluded that fruit size and final weight is determined to a large extent by the leaf area supplying food to the fruit. Slips less than $30 \mathrm{~cm}$ resulted in fewer fruits with inferior average weight. Best results were obtained with slips $35-45 \mathrm{~cm}$ long. Py (26) reports that when compared with 250- and 450-g slips 350-g Smooth Cayenne slips yielded superior fruit $(1.765 \mathrm{~kg})$. In a previous report Py (25) presented evidence that large slips produced fruits averaging $1641 \mathrm{~g}$ against 1566 and $1287 \mathrm{~g}$ for medium and small slips, respectively.

Reynhardt and Dalldorf (29), working with crowns, slips and suckers, concluded that $300 \mathrm{-g}$ and $33-\mathrm{cm}$ slips produced the best results for Smooth Cayenne, whereas suckers 228 and $45 \mathrm{~cm}$ long presented the best combination for cv. Queen.

Bourke (3), using five types of propagules with Queen concluded from data of 5 years that aerial suckers are the best material when compared with slips, ground suckers (ratoon), crowns and butts or stumps. There were significant differences in the original weight of the planting material.

Mitchell (20) reported that heavier crowns produced larger plants, more slips and heavier fruits. He found that slips and crowns of the same weight resulted in almost identical plant development and yield. Using " $D$ " leaf size as reference, he concluded that heavier material produced larger plants at the point of flower induction. He suggested that smaller propagules should be planted earlier to obtain optimum fruit size.

Chadha (4) in India used five slip sizes (150-600 grams) with cultivar Kew. Number of leaves at 12 months old varied between 26.4 to 37.5 , with the highest numbers in the heavier material. At flowering time the number of leaves ranged from 30.4 to 39.8 ; these differences were highly significant. He concluded that the number of leaves at planting time must be the basis for the difference in plant growth. Plant vigor as 
measured by leaf area index (32) did not vary significantly among treatments (272.67 to $\left.322.09 \mathrm{~cm}^{2}\right)$. According to Chadha this index is not a suitable method to determine vigor and yielding potential of the plant. He suggested sucker production was the best indication, because maximum numbers of suckers were produced in the largest slip size.

Balakrishnan (2) from the Pineapple Research Center at Kerala Agricultural University worked with the Kew cultivar. He tried material weighing 130 to 650 grams with 8 to 32 leaves. He concluded that size of sucker need not be taken as a major criterion in pineapple cultivation when good management practices exist. His data present highly significant differences in number of leaves (37-46) at 18 months when flowering was induced artificially. Leaf area of the "D" leaf at that point did not show significant differences.

Norman (21), working with Sugarloaf variety, used 80-g crowns, 136-g slips and 450-g suckers. He concluded that planting material did not influence fruit yield, size or quality. His data on vegetative growth taken at harvest showed significant differences in leaf number (43-52) and in plant height $(95-102 \mathrm{~cm})$. Plants originating from crowns were the most vigorous, whereas those from suckers were the smallest.

In Puerto Rico, Gandia and Samuels (16) claim that size of slip stem is more reliable than foliage as a measure of potential yield. Large slips or suckers will produce premature flowering plants which yield small fruits (7).

Research in other places ${ }^{3}$ suggests a high correlation between number of leaves per plant and size of fruit $(5,6,22,30,31)$. Van Overbeek (30, 31 ) found a highly significant correlation (.76) between these two variables, claiming the average size of the fruit can be predicted at induction time. In Hawaii they use plant weight as criterion to determine when to induce flowering to obtain desirable fruit size. Size and weight of the " $D$ " leaf is also mentioned as a measure related to vigor and yield of the pineapple plant. Py (24) suggested that weight of the "D" leaf at induction time can be an indication of vegetative vigor and weight of fruit to be produced. Weight of the " $\mathrm{D}$ " leaf was influenced only and directly by the size of planting material used. Correlations as high as .95 have been reported in Hawaii between " $D$ " leaf weight and estimated weight of the plant. Py (27) reported a correlation of .96 between theoretical foliage mass at induction time and fruit weight. He also states that the leaf " $\mathrm{D}$ " weight at a given moment can give a wrong idea of plant development.

Foliage pruning of planting material has been mentioned to reduce wind toppling and shipping volume, and to facilitate both traditional and

\footnotetext{
${ }^{3}$ Sanford, W. G., Honolulu, Hawait, personal communication
} 
mechanical planting $(1,15,18,23,28,29)$. Sanford ${ }^{3}$ mentions that pruning terminal foliage of slips is a detrimental practice. Henricksen (18) reported that cutting or breaking the leaves lowered the vitality of the plant. Leaf pruning in Cabezona variety reduced yield and size of the fruit (8). Research in Hawaii to improve machinery planting proved that pruning foliage from 12.5 to $25 \mathrm{~cm}$ significantly reduced both plant and fruit weight. Foliage elimination was detrimental. Twenty-one days were required to harvest $95 \%$ on unpruned slips; 62 days for pruned slips. Fruit weight was 1950 and $1620 \mathrm{~g}$, respectively. Reports from Australia and Africa $(28,29)$, claim that pruning stumps improves behaviour. According to Gadelha (12) planting of pineapple in upright (vertical) position is an operation accounting for increasing production costs. He compared 45 and 90 degrees planting positions with 50-70 g Perola slips. Heavier and larger fruits were obtained with the vertical position. Plants were also larger and with more slips. Results from using suckers (13) were still worse, since they never attained a vertical position because of premature flowering five months after planting. There was a $100 \%$ fruit sunscald due to peduncle breakage.

Reynhardt compared vertical versus horizontal planting using Smooth Cayenne stumps. Better results were obtained with the upright position. Giacommelli (17) and Py (27) mentioned inclined slip plantings in Martinica and Brazil. They describe the $45^{\circ}$ planting position as more practical and efficient. After a few weeks, plants assume the normal vertical position. Janick (19) states that several fruit trees planted at $45^{\circ}$ angle exhibited reduced growth and an earlier flowering, probably because of disturbances in auxin movement.

\section{MATERIALS AND METHODS}

Pineapple slips of a first crop of Smooth Cayenne planting were classified according to size in four categories (A-large; B-medium; Caverage; D-small). They were cured under shade for 3 weeks. Basal leaves or "scales" were removed and slips treated with .15\% demeton and benomyl. ${ }^{4}$ Size A slips were divided in four groups; $0,15,20$ and $25 \mathrm{~cm}$ was removed from the tip foliage. All slips were measured and weighed. Half were planted in a vertical position (treatments 1 to 7 ). Treatments 8 to 14 were planted in an inclined position (45\%). There were 36 plants per experimental unit with three replications in a double row system spaced at $100 \times 50 \times 40 \mathrm{~cm}$. Slip samples were taken to determine

\footnotetext{
${ }^{4}$ Demeton $-S-$ methyl - 0'0-dimethyl S-2(ethylthio) ethyl phosphorothioate; benomyl $=$ methyl 1 - butylearbamoyl)-2-benzimidazolecarbamate; captafol = Cis-N-(1,1,2,2-tetrachloroethyl) thio)4-cyclohexene-1,2 dicarboximide; ridomil = methyl D L-N-(2,6-dimethylphenyl) $\mathrm{N}-2$-methoxyacetyl-alaninate; mancozeb = zinc ion and manganese ethylene bisdithiocarbamate; diuron $=3-(3,4$-dichlorophenyl $)-1,1$-dimethyl urea.
} 
number of leaves, weight, length and diameter of stem after stripping (table 1). Planting date was April 22, 1983 with a $13.89 \%$ replanting June 15 because of heart rot (Phytophthora cinnamoni, $P$. nicotianae var. parasitica). Plants were sprayed with captafol, ${ }^{4}$ ridomil, ${ }^{4}$ and mancozeb. ${ }^{4}$ Diuron ${ }^{4}$ was used to control weeds. Fertilization included urea, triple superphosphate and potassium chloride (10-5-20). Soil analysis showed the following characteristics:

Acidity ( $\mathrm{pH})$

Organic matter

Available phosphates

Available potassium

Available calcium

Exchangeable aluminum

Soil texture

\section{8}

$2.4 \%$

$45 \mathrm{p} / \mathrm{m}$

$110 \mathrm{p} / \mathrm{m}$

$290 \mathrm{p} / \mathrm{m}$

$0.3 \mathrm{me} / 100 \mathrm{~g}$

Sandy loam

TABLE 1.-Characteristics of slips used in the experiment (mean values)

\begin{tabular}{lcccccc}
\hline \multicolumn{1}{c}{ Treatment } & $\begin{array}{c}\text { Slip } \\
\text { length }\end{array}$ & $\begin{array}{c}\text { Slip } \\
\text { weight }\end{array}$ & $\begin{array}{c}\text { Number } \\
\text { of leaves }\end{array}$ & $\begin{array}{c}\text { Stem } \\
\text { weight }\end{array}$ & $\begin{array}{c}\text { Stem } \\
\text { diameter }\end{array}$ & $\begin{array}{c}\text { Stem } \\
\text { length }\end{array}$ \\
\hline & $\mathrm{cm}$ & $\begin{array}{c}\mathrm{g} \\
\text { Vertical }\end{array}$ & & $\mathrm{g}$ & $\mathrm{cm}$ & $\mathrm{cm}$ \\
1A Large pruned $0 \mathrm{~cm}$ & 42 & 327 & 50 & 42.8 & 3.1 & 6.5 \\
2A Large pruned $15 \mathrm{~cm}$ & 27 & 278 & - & - & - & - \\
3A Large pruned $20 \mathrm{~cm}$ & 22 & 267 & - & - & - & - \\
4A Large pruned $25 \mathrm{~cm}$ & 17 & 252 & - & - & - & - \\
5B Medium unpruned & 34 & 231 & 46 & 29.8 & 2.4 & 5.4 \\
6C Average unpruned & 29 & 154 & 42 & 21,8 & 2.2 & 4.8 \\
7D Small unpruned & 23 & 94 & 35 & 12.4 & 1.9 & 4.0 \\
\hline
\end{tabular}

${ }^{1} 8-14$ Same treatments planted in an inclined position $\left(45^{\circ}\right)$.

The following data was obtained from 18 plants 12 months after planting: number of visible leaves with $50 \%$ or more green area; number of visible entire leaves with $100 \%$ green area; plant spread (widest point); plant height (undisturbed); and weight, length, width and thickness of "D" leaf. Width was taken at the widest point of the leaf green area, 25$30 \mathrm{~cm}$ from the leaf base. Thickness was taken at the same point.

A sample of 75 plants was used to determine weight and stripped number of leaves; weight and diameter of stem and to study correlations between similar characteristics. Observations were made on disease incidence, toppling over of plants, stem position and survival of pruned leaves.

\section{RESULTS AND DISCUSSION}

Weight of slip stem accounted for 12.9 to $14.2 \%$ of total slip weight. Correlation between both characteristics was very high (.9588, table 2$)$. 
According to Py (27) foliar mass is around $88 \%$ of plant total weight. Apparently this is also true for Smooth Cayenne slips.

Number of leaves in slips was determined by stripping and considering green folioles or scales $2 \mathrm{~cm}$ or longer as leaves. Those in the center of the growing point with no green pigment were also considered. Number of leaves varied from 35 to 50 according to size of slip. It has been mentioned that for propagation purposes size of stem is more important than slip size. Stem diameter at its widest point ranged from 1.9 to 3.1 $\mathrm{cm}$, whereas length varied from 4.0 to $6.5 \mathrm{~cm}$. There was a correlation of .8833 between stem weight and length and .86 between stem diameter and slip weight. Correlation between slip length and weight was .9241, larger than that with stem diameter (table 2).

Leaf pruning must be very drastic to obtain equivalent weights in unpruned slips. Slips $42 \mathrm{~cm}$ long pruned to $17 \mathrm{~cm}$ were heavier than unpruned slips $34 \mathrm{~cm}$ long. Pruned leaf section was very light. When 25

TABLE 2.-Correlation coefficients between six characteristics in a sample of 82 slips

\begin{tabular}{lcccccc}
\hline \multicolumn{1}{c}{ Variable } & $\mathrm{A}$ & $\mathrm{B}$ & $\mathrm{C}$ & $\overline{\mathrm{D}}$ & $\mathrm{E}$ & $\mathrm{F}$ \\
\hline A Slip weight & - & $.9241^{* * 1}$ & $.5438^{* *}$ & $.9588^{* *}$ & $.8600^{* *}$ & $.8833^{* *}$ \\
B Slip length & - & - & $.3700^{* *}$ & $.8661^{* *}$ & $.7214^{* *}$ & $.8459^{* *}$ \\
C Number of & - & - & - & $.5463^{* *}$ & $.7797^{* *}$ & $.4162^{* *}$ \\
$\quad$ stripped leaves & & & & & & \\
D Stem weight & - & - & - & - & $.8606^{* *}$ & $.9295^{* *}$ \\
E Stem diameter & - & - & - & - & - & $.7317^{* *}$ \\
F Stem length & - & - & - & - & - & - \\
\hline
\end{tabular}

'Significant at the $1 \%$ probability level.

$\mathrm{cm}$ of foliage was removed, $59.5 \%$ of slip length was eliminated accounting for only $22.94 \%$ of total weight.

After 12 months there was no visual difference in plants set in a vertical or inclined position. Six months after planting inclined slips had acquired a vertical position and it was extremely difficult to discriminate between planting positions. Analysis of data did not show differences (table 3).

There was not a single case of toppling over. Slips planted in a vertical position showed higher incidence of heart rot (Phytophthora), $17 \%$ as compared to $11 \%$ in the inclined position.

These results do not agree with Gadelha $(12,13)$ and Reynhardt $(29)$ because of the differences in planting material. It is very probable that they used stock already with flower differentiation. Results agree with Py and Giacomelli $(17,27)$ suggesting that the planting operation could be more efficient when the inclined position is used. 
Results from this experiment indicate that slip foliage pruning can affect vegetative development of the pineapple plant. As a consequence, a reduction in yield might be expected. Unpublished information from the Pineapple Research Institute in Hawaii indicates this practice had detrimental effects on development and yield.

Slips with no pruning produced taller plants with more entire green leaves, thus suggests a larger photosynthetic area. When pruned leaves or those having more than $50 \%$ green area were counted, differences were

\begin{tabular}{|c|c|c|c|c|c|c|}
\hline \multirow[b]{2}{*}{ Leaves } & \multicolumn{2}{|l|}{ Plant } & \multicolumn{4}{|c|}{ “I)" I.eaf } \\
\hline & Height & Spread & Jengrh & Width & Weight & Thickness \\
\hline no. & $\mathrm{cm}$ & $\mathrm{cm}$ & $\mathrm{cm}$ & $\mathrm{cm}$ & $g$ & $\mu m$ \\
\hline 44.9 & 58.9 & I01.7 & $\begin{array}{c}\text { Vertical } \\
71.20 \\
45^{\circ}\end{array}$ & 5.48 & 45.6 & 223.5 \\
\hline 44.9 & 57.6 & 104.1 & 69,82 & 5.70 & 43.7 & 224.4 \\
\hline
\end{tabular}

TABL.E 4.-Effect of pruning in vegetative development of 12 -month pineapple plants

\begin{tabular}{|c|c|c|c|c|c|c|c|c|}
\hline \multirow[b]{2}{*}{ Pruned } & \multicolumn{3}{|c|}{ Plant } & \multirow[b]{2}{*}{$\begin{array}{l}\text { Spread } \\
\mathrm{NS}^{*}\end{array}$} & \multicolumn{4}{|c|}{ "D" leaf } \\
\hline & $\begin{array}{c}\text { No. } \\
\text { of } \\
\text { leaves } \\
\text { NS }\end{array}$ & $\begin{array}{l}\text { Enlire } \\
\text { green } \\
\text { leaves }\end{array}$ & Heisht ${ }^{*}$ & & Weight & $\begin{array}{l}\text { Length } \\
\text { NSS }\end{array}$ & $\begin{array}{c}\text { Width } \\
\text { NS }\end{array}$ & $\begin{array}{c}\text { Thickness } \\
\text { NS }\end{array}$ \\
\hline $\mathrm{cm}$ & & & $\mathrm{cm}$ & $\mathrm{cm}$ & $g$ & $\mathrm{~cm}$ & $\mathrm{~cm}$ & $\mu m$ \\
\hline 0 & 49.6 & 42.3 & 65.4 & 109.0 & 50.06 & 73.90 & 5.70 & 234.2 \\
\hline 15 & 47.8 & 39.4 & 61.9 & 107.7 & 46.28 & 71.08 & 5.18 & 226.7 \\
\hline 20 & 47.4 & 38.1 & 62.3 & 110.7 & 48.82 & 74.48 & 5.82 & 227.5 \\
\hline 25 & 46.9 & 37.9 & 59.2 & 105.7 & $43.5^{\circ}$ & 71.06 & 5.58 & 227.0 \\
\hline Check & 49.6 & 42.3 & 65.4 & 109.0 & 50.06 & 73.90 & 5.70 & 234.2 \\
\hline Pruned & 47.1 & 38.5 & 61.1 & 108.03 & 46.21 & 72.20 & 5.53 & 227.1 \\
\hline
\end{tabular}

${ }^{1}$ Significant at the $1 \%$ level.

${ }^{2}$ Significant at the $5 \%$ level.

${ }^{3}$ Nol significant.

not significant as happened with plant spread. Pruning treatments did not differ among them. Data on " $D$ " leaf showed significant differences in weight but not in length, width or thickness. Unpruned slips produced heavier and slightly thicker leaves and having in all cases larger leaves (table 4). Many of the pruned leaves were still functional 1 year later. In all cases pruned slips were affected to a greater degree by heart rot (16.82 vs. $5.56 \%$ ). Exposure of growing point and pruning lesions could facilitate disease incidence. 
JOURNAL OF AGRICULTURE OF UNIVERSITY OF PUERTO RICO

TABLE 5.-Effect of slip size on the vegetative development of 12-month-old plants

\begin{tabular}{|c|c|c|c|c|c|c|c|c|c|}
\hline \multicolumn{3}{|c|}{ Treatment } & \multicolumn{3}{|c|}{ Plant } & \multicolumn{4}{|c|}{ "D" lear } \\
\hline Size & Height & Weight & $\begin{array}{c}\text { Number } \\
\text { of } \\
\text { leaves }\end{array}$ & $\begin{array}{l}\text { Plant } \\
\text { height }^{* *}\end{array}$ & Spread** & Wejght ${ }^{* *}$ & Length ${ }^{* *}$ & $\begin{array}{l}\text { Width } \\
\text { NS }^{2}\end{array}$ & $\begin{array}{l}\text { Thick- } \\
\text { ness }^{* *}\end{array}$ \\
\hline & $\mathrm{cm}$ & $g$ & & $\mathrm{~cm}$ & $\mathrm{~cm}$ & $g$ & $\mathrm{~cm}$ & $\mathrm{~cm}$ & $\mu m$ \\
\hline A Large & 42 & 327 & 49.6 & 65.4 & 109.0 & 50.06 & 73.9 & 5.70 & 234.2 \\
\hline B Medium & 34 & 231 & 45.2 & 60.2 & 108.1 & 46.65 & 71.4 & 5.73 & 226.8 \\
\hline C Average & 29 & 154 & 40.9 & 54.2 & 105.1 & 43.43 & 69.9 & 5.83 & 218.0 \\
\hline D Small & 23 & 94 & 36.3 & 44.5 & 94.5 & 33.72 & 61.8 & 5.28 & 207.3 \\
\hline
\end{tabular}

1 Significant at the $1 \%$ probability level.

${ }^{2}$ Not significant.

TABLE 6.-Vegetative development of Smooth Cayenne plants as affected by planting position, slip pruning and size

\begin{tabular}{|c|c|c|c|c|c|c|c|}
\hline Treatment & $\begin{array}{c}\begin{array}{c}\text { Number } \\
\text { of } \\
\text { leaves }\end{array} \\
\end{array}$ & Treatment & $\begin{array}{l}\text { Plant } \\
\text { height }\end{array}$ & Treatment & $\begin{array}{l}\text { Plant } \\
\text { spread }\end{array}$ & Treatment & $\begin{array}{c}\text { No. of } \\
\text { entire green } \\
\text { leaves }\end{array}$ \\
\hline & & & $\mathrm{cm}$ & & $\mathrm{cm}$ & & \\
\hline 8 & $50.3 a^{\prime}$ & 1 & $66.7 \mathrm{a}$ & 3 & 116.4 a & 8 & $42.8 \mathrm{a}$ \\
\hline 1 & 48.8 a & 8 & $64.1 \mathrm{ab}$ & 1 & $111.2 \mathrm{ab}$ & 1 & $41.8 \mathrm{ab}$ \\
\hline 9 & $48.7 \mathrm{ab}$ & 3 & $63.9 \mathrm{ab}$ & 2 & $109.2 \mathrm{abc}$ & 9 & $40.1 \mathrm{abc}$ \\
\hline 3 & $47.7 \mathrm{ab}$ & 9 & $63.3 \mathrm{ab}$ & 5 & 108.6 abc & 3 & $39.6 \mathrm{bcd}$ \\
\hline 4 & $47.4 \mathrm{ab}$ & 2 & $60.6 b c$ & 12 & $107.6 \mathrm{abc}$ & 2 & $38.8 \mathrm{~cd}$ \\
\hline 10 & $47.1 \mathrm{ab}$ & 10 & $60.5 b c$ & 11 & $107.1 \mathrm{abc}$ & 4 & $38.0 \mathrm{~cd}$ \\
\hline 2 & $46.9 \mathrm{ab}$ & 12 & $60.3 \mathrm{bc}$ & 8 & $106.8 \mathrm{abc}$ & 11 & $37.8 \mathrm{~cd}$ \\
\hline 11 & $46.3 \mathrm{ab}$ & 5 & $60.2 b c$ & 9 & $106.3 \mathrm{abc}$ & 10 & $36.7 \mathrm{~d}$ \\
\hline 12 & 46.0 abc & 11 & 59.3 bc & 6 & $105.3 \mathrm{abc}$ & & \\
\hline 5 & $44.5 b c$ & 4 & $58.8 \mathrm{bc}$ & 10 & $105.1 \mathrm{abc}$ & & \\
\hline 6 & $42.2 \mathrm{~cd}$ & 6 & $55.9 \mathrm{~cd}$ & 13 & $104.9 \mathrm{bc}$ & & \\
\hline 13 & $39.7 \mathrm{de}$ & 13 & $52.4 \mathrm{~d}$ & 4 & $104.4 \mathrm{bc}$ & & \\
\hline 7 & $36.4 \mathrm{e}$ & 7 & $45.8 \mathrm{e}$ & 7 & $97.6 \mathrm{~cd}$ & & \\
\hline 14 & $36.2 \mathrm{e}$ & 14 & $43.0 \mathrm{e}$ & 14 & $91.3 \mathrm{~d}$ & & \\
\hline
\end{tabular}

${ }^{1}$ Means followed by one or more letters in common do not differ significantly at the $5 \%$ probability level using Duncan's Multiple Range Test.

Growing conditions in this experiment were very favorable; plants were exuberant and vigorous. Leaves were succulent and brittle, many attaining $8 \mathrm{~cm}$ in width. It is probable this condition reduced pruning effect and stimulated rapid recuperation.

All variables, except " $D$ " leaf width, showed highly significant differences. Plant development was nearly proportional to slip size (table 5). Leaf number varied between 36 and 50 , and plant height ranged between 45 to $65 \mathrm{~cm}$ (table 6). Similar findings were reported by Gadelha (10) with Perola pineapple, Chadha (4) with Kew and Norman (21) with Sugarloaf. Plant spread did not show differences among the three largest sizes. Spread ranged between 95 and $109 \mathrm{~cm}$. Leaf " $\mathrm{D}$ " weight, length 
and thickness showed highly significant differences (table 7). Similar results were reported by Mitchell (20), who found that weight and length of " $D$ " leaf; plant height and leaf number were larger according to size and weight of the planting material.

Correlation coefficients between " $\mathrm{D}$ " leaf weight, and leaf number and

TABLE 7-_ "D" leaf development as affected by planting position, slip pruning and size

\begin{tabular}{rlrcrrrr}
\hline Treatment & $\begin{array}{c}\text { "D" leaf } \\
\text { weight }\end{array}$ & Treatment & Length & Treatment & Width & Treatment & Thickness \\
\hline & \multicolumn{1}{c}{$g$} & & $c m$ & & $c m$ & & $c m$ \\
3 & $51.9 \mathrm{a}^{\mathrm{l}}$ & 3 & $77.5 \mathrm{a}$ & 12 & $5.97 \mathrm{a}$ & 1 & $234.3 \mathrm{a}$ \\
1 & $51.6 \mathrm{ab}$ & 1 & $74.9 \mathrm{ab}$ & 13 & $5.97 \mathrm{a}$ & 8 & $234.0 \mathrm{a}$ \\
8 & $48.5 \mathrm{abc}$ & 8 & $72.9 \mathrm{ab}$ & 3 & $5.93 \mathrm{a}$ & 11 & $231.7 \mathrm{a}$ \\
9 & $47.9 \mathrm{abc}$ & 9 & $71.9 \mathrm{ab}$ & 1 & $5.90 \mathrm{a}$ & 12 & $229.3 \mathrm{ab}$ \\
5 & $46.9 \mathrm{abc}$ & 12 & $71.8 \mathrm{ab}$ & 11 & $5.80 \mathrm{a}$ & 10 & $228.3 \mathrm{ab}$ \\
12 & $46.4 \mathrm{abc}$ & 10 & $71.5 \mathrm{~b}$ & 10 & $5.70 \mathrm{ab}$ & 2 & $227.0 \mathrm{abc}$ \\
10 & $45.6 \mathrm{abc}$ & 11 & $71.3 \mathrm{~b}$ & 6 & $5.70 \mathrm{ab}$ & 3 & $226.7 \mathrm{abc}$ \\
2 & $44.6 \mathrm{bc}$ & 5 & $70.9 \mathrm{~b}$ & 14 & $5.53 \mathrm{abc}$ & 9 & $226.3 \mathrm{abc}$ \\
6 & $44.3 \mathrm{c}$ & 6 & $70.8 \mathrm{~b}$ & 8 & $5.50 \mathrm{abc}$ & 6 & $224.7 \mathrm{abc}$ \\
4 & $43.9 \mathrm{c}$ & 4 & $70.8 \mathrm{~b}$ & 5 & $5.50 \mathrm{bc}$ & 5 & $224.3 \mathrm{abc}$ \\
11 & $43.1 \mathrm{c}$ & 2 & $70.2 \mathrm{~b}$ & 9 & $5.43 \mathrm{bc}$ & 4 & $222.3 \mathrm{abc}$ \\
13 & $42.6 \mathrm{c}$ & 13 & $68.9 \mathrm{~b}$ & 4 & $5.37 \mathrm{bc}$ & 13 & $211.3 \mathrm{bcd}$ \\
7 & $35.9 \mathrm{~d}$ & 7 & $63.3 \mathrm{c}$ & 7 & $5.03 \mathrm{bc}$ & 14 & $209.7 \mathrm{~cd}$ \\
14 & $31.5 \mathrm{~d}$ & 14 & $60.3 \mathrm{c}$ & 2 & $4.93 \mathrm{c}$ & 7 & $205.0 \mathrm{~d}$ \\
\hline
\end{tabular}

'Means followed by one or more letters in common do not differ significantly at the $5 \%$ probability level using Duncan Multiple Range Test.

TABLE 8.-Correlation coefficients in 1-year-old plants obtained from four slip sizes with no pruning treatment $(N=288)$

\begin{tabular}{lccccc}
\hline & $\mathrm{A}$ & $\mathrm{B}$ & $\mathrm{C}$ & $\mathrm{D}$ & $\mathrm{E}$ \\
\hline Leal number (A) & - & $.8389^{* * * 1}$ & $6511^{* *}$ & $.7562^{* *}$ & $.7024^{* *}$ \\
Plant height (B) & - & - & $.7138^{*}$ & $.7770^{* *}$ & $.7900^{* *}$ \\
Plant spread (C) & - & - & - & $.7852^{* *}$ & $.8708^{* *}$ \\
"D" leaf weight (D) & - & - & - & - & $.7950^{* *}$ \\
"D" leaf length (E) & - & - & - & - & - \\
\hline
\end{tabular}

' Significant at the $1 \%$ probability level.

plant height were .7562 and .7770 , both highly significant. Coefficients between " $D$ " leaf length and leaf number and plant height were .7024 and .7900 , respectively (table 8 ). Highest correlation of " $D$ " leaf weight was associated with plant weight (.7937 table 9). There were consistent correlations between stem and slip weight, .9588; stem and plant weight, .8888; stem diameter and slip weight, .8600; and stem diameter and plant weight, .9310 ; all correlations were highly significant. 
TABLE 9.-Correlation coefficients between nine variables in 1-year-old plants obtained from four slip sizes $(N=75)$

\begin{tabular}{|c|c|c|c|c|c|c|c|c|c|}
\hline & A & B & $\mathrm{c}$ & D & $\mathrm{E}$ & $\mathbf{F}$ & G & $\mathrm{H}$ & 1 \\
\hline $\begin{array}{l}\text { Number of visible } \\
\text { leaves }(A)\end{array}$ & - & $.5033^{* *}$ & $.4303^{* *}$ & $.8598^{* *}$ & * . $9639 * *$ & $.7895^{* *}$ & $.8371^{* *}$ & *5656** & $.3972^{* *}$ \\
\hline Plant height (B) & - & - & $.5569^{* *}$ & $.6355^{* *}$ & $.5760^{* *}$ & $.5820^{* *}$ & $.5282^{* * *}$ & $.6204^{* *}$ & $.5517^{* * *}$ \\
\hline Plant spread (C) & - & - & - & $.6687^{* *}$ & $.4524^{* *}$ & $.6580^{* *}$ & $.5515^{* *}$ & $.6943^{* *}$ & $.8100^{* * *}$ \\
\hline Plant weight (D) & - & - & - & - & $.8783^{* *}$ & $.9310^{* *}$ & $.8888^{* *}$ & $.7937^{* *}$ & $.6400^{* *}$ \\
\hline $\begin{array}{l}\text { Number of stripped } \\
\text { leaves (E) }\end{array}$ & - & - & - & - & - & $.7966^{* *}$ & $.8268^{* *}$ & $.6099^{* *}$ & $.4196^{* *}$ \\
\hline Stem diameter (F) & - & - & - & 一 & - & - & $.8732^{* *}$ & $.7136^{* *}$ & $6079^{* *}$ \\
\hline Stem weight (G) & - & - & - & - & - & - & - & $.5994^{* *}$ & $.5131^{* *}$ \\
\hline "D" leaf weight (H) & - & -- & - & - & - & - & - & - & $.5899^{* *}$ \\
\hline "D" leaf length (I) & - & - & - & - & - & - & - & - & - \\
\hline
\end{tabular}

\section{RESUMEN}

Este experimento incluyó dos posiciones de siembra (45 y 90 grados), cuatro pesos de hijuelos $(327,231,154$ y 94 gramos, correspondiendo a tamaños de $42,34,29$ y $23 \mathrm{~cm}$.). El tamaño mayor se dividió en cuatro partes para podar a $0,15,20$ y $25 \mathrm{~cm}$. del ápice hacia la base. Había 36 plantas por unidad experimental con tres repeticiones.

A los 12 meses de edad se midió la altura, la extensión (spread), el peso, la longitud, la anchura, el espesor de la hoja "D" y se contaron las hojas por planta.

Los resultados demostraron que la posición de siembra no afectó el desarrollo vegetativo. La poda disminuyó la altura de la planta, el número de hojas enteramente verdes y el peso de la hoja " $D$ ", pero no hubo diferencia entre las tres intensidades de poda. Las diferencias más conspicuas se encontraron entre los distintos tamaños de los hijuelos usados. Esta variable mostró diferencias altamente significativas en todas las caracteristicas excepto la anchura de la hoja. El desarrollo vegetativo fue proporcional al tamaño del hijuelo usado, a pesar de que las condiciones de clima y suelo fueron muy favorables para el desarrollo, por to cual el crecimiento fue vigoroso y las plantas suculentas. La correlación entre las variables observadas fueron altamente significativas; las mayores y más consistentes fueron los pesos de las plantas, los hijuelos, el tallo y el diámetro del tallo. Las pruebas de comparación múltiple demostraron la centralización de resultados en dos grupos según el tamaño del hijuelo. Bajo las condiciones de este experimento, los pesos de menos de 200 gramos no compararon favorablemente. También se agrupan las tres intensidades de poda indicando poca diferencia entre eliminar de 15 a 25 $\mathrm{cm}$. del ápice de los hijuelos.

No hubo caída de las plantas. Los brotes podados fueron significativamente más afectados por la podredumbre del corazón (16.82 contra 
$5.56 \%)$. Hubo mayor incidencia de la enfermedad en plantas sembradas verticalmente (17 contra $11 \%$, N.S.)

\section{LITERATURE CITED}

1. Araque, R. 1963, La piña. Consejo de Bienester Rural. Caracas, Venezuela.

2. Balakrishman, S., N. R. Nayar and V. Mathew, 1981. Effect of size of suckers on growth and yield in pineapple (Ananas comosus. MERR.) cv. Kew. Agric. Res. J. Kerala, 19 (1): $1-4$.

3. Bourke, R. M., 1976. A comparison of five types of planting material for rough leaf pineapples. Papua New Guinea Agric. J. 27 (4).

4. Chadha, K. L., K. R. Melanta and S. D. Shikhamany, 1974. Effect of the type and size of planting material on the vigour of the subsequent plant, yield and quality in Kew pineapple (Ananas comosus) (L) (Merr.). Indian J. Hortic. 31 (1).

5. Cooper, W. C. and P. C. Reese, Induced flowering of pineapples under Florida conditions. Bureau of Plant Industry, USDA, Orlando, Fla.

6. De Fernández, M. del C. C., 1956. Aplicación de hormonas y otras prácticas para producir la floración en la piña. Rey. Agric. P.R. 44 (1).

7. Estación Experimental Agricola, Colegio de Ciencias Agricolas, Recinto de Mayagüez, Univ. P.R., 1976. Conjunto Tecnológico para la Produeción de Piña. Publ. 106.

8. Estación Experimental Agrícola. Colegio de Ciencias Agricolas Recinto de Mayagüez, Univ. P.R., Informe Anual 1982-83.

9. Fortes, J. M., 1970. Intluência do tamanbo da muda de Abacaxi, Anonas comosus (L) Merr., sóbre o número e pêso médio dos frutos. Tese, Universidade Federal de Vicosa, Vicosa, Minas Gerais, Brasil.

10. Gadelha, R. S. de S. e H. de 0 . Vasconcellos, 1977. Influència do tamanho e péso das mudas de abacaxi; Ananas comosus (L). Merr. no desenvolvimento da planta e na qualidade do fruto. Pesq. Agropec. Bras. Brasilia, 12:151-56.

11. — e - 1979. Influéncia do pêso da muda tipo "fillhote" no ciclo natural do abacaxi cv. Perola, Pesq. Agropec. Bras, Brasilia 14 (1).

12. - e - 1979. Influência da posição da muda tipo "fillhote" no plantio do abacaxi cv. "Perola", Pesq. Agropec. Bras. Brasilia 14 (2): 123-24.

13. - - - , e J. F. Da Costa, 1978. Posição da muda tipo "rebentao" no plantio do abacaxi cv. Perola, Pesq. Agropec. Bras., Brasilia 13 (3): 7-9.

14. Gaillard, J. P. 1969. Influence de la date de plantation et du poids des rejets sur la croissance des ananas en Cameroun. Fruits d'Outre Mer 24 (2): 75-87.

15. Gajón Sánchez, C., 1947. Cultivo de la Piña. Ediciones Agrícolas "Trucco" México, D. F.

16. Gandía Diaz, H. y G. Samuels, 1958. Cultivo y Elaboración de la Piña en Puerto Rico, Esta. Exp. Agric. Univ. P, R., Bol, 145.

17. Giancomelli, E. J. e C. Py, O Abacaxi no Brasil. Fundación Cargill. Brasil.

18. Henricksen, H. C. and M. J. Iorns, 1909. Pineapple Growing in Porto Rico, Porto Rico Agric. Exp. Stn, Mayaguiez, Bull 8.

19. Janick, J., Horticultura Cientitica e Industrial. Edición Española de "Horticultural Science". Editorial Acribia, España.

20. Mitchell, A. R, 1962. Plant development and yield in the pineapple as affected by size and type of planting material and times of planting and forcing, Queensl. J. Agric. Sci. 19: 453-66.

21. Norman, J. C., 1978. Influence of planting materials on growth, flowering and fruiting of "Sugarloaf" pineapple, Ananas comosts (L) Merr., Acta Hortic. 84: 191-97.

22. Pérez, V. M., Como producir piña durante todo el afio. Hoja Divulgativa No. 5. Ministerio de Agricultura e Industrias STICA, San José, Costa Rica. 


\section{JOURNAL OF AGRICULTURE OF UNIVERSITY OF PUERTO RICO}

23. Platts, P. K., 1950. Pineapple ABC's Dep. Agric., State of Florida.

24. Py, C., 1958. Prevision de recolte en culture d'ananas. Fruits d'Outre Mer 13:243-51.

25. — 1955. Les differents types de rejets d'ananas. Fruits 10 (1).

26. — 1960. Le stockage des rejets d'ananas en saison sèche. Fruits 15 (1).

27. —_, 1967. La Piña Tropical. Editorial Blume, Barcelona, España.

28. Queenstand Department of Agriculture and Stock, 1959. The Pineapple. Officers of the Horticulture Branch. Advisory Leaflet No 286.

29. Reynhardt, J. P. K. and E. R. Dalldorf, 1968. Planting Material for the Cayenne Pineapple, Agric. Res. Stn. East London, South Africa. Farming in S.A. 44 (2).

30. Van Overbeek, J., 1946. Control of flower formation and fruit size in the pineapple, Bot. Gaz. 108: 64-73.

31. -.., 1951. Use of growth substances in tropical agricultures. Plant Growth Substances, Folke Skoog, (Ed) Univ. Wis, Press.

32. Wu, Y. C. and N. R. Su, 1965. Response of pineapples growing on a latosol to phosphorus, magnesium and variously applied potassium, J. Agric. Ass. China 49: $48-64$. 